\title{
Development of an enzyme-linked immunosorbent assay (ELISA) to estimate the quantity of Flavobacterium branchiophilum on the gills of rainbow trout Oncorhynchus mykiss
}

\author{
D. D. MacPhee*, V. E. Ostland, J. S. Lumsden, H. W. Ferguson \\ Fish Pathology Laboratory, Department of Pathology, Ontario Veterinary College, University of Guelph, Guelph, Ontario, \\ Canada N1G 2W1
}

\begin{abstract}
An enzyme-linked immunosorbent assay (ELISA) was developed to estimate the quantity of Flavobacterium branchiophilum in crude gill extracts from rainbow trout Oncorhynchus mykiss following bath exposure to the bacterium. The assay utilized the avidin-biotin system and polyclonal antiserum raised against the LAB 4 a strain of $F$, branchiophilum. The detection threshold was ca $1 \times 10^{3}$ bacteria $\mathrm{mL}^{-1}$, and during routine use the mean intra-assay and inter-assay variations were $6.7 \%$ and $8.1 \%$, respectively. The ELISA absorbance $(405 \mathrm{~nm})$ was proportional to the amount of $F$ branchiophilum present (within a range of antigen concentration of 0 to 80000 cells $\mathrm{ml}^{-1}$ ) whether whole bacterial cell preparations, gill preparations spiked with bacterial cells or extracts of infected gills were tested. In a comparison of whole cell preparations derived from the type strain of $F$ branchiophilum (American Type Culture Collection 35035), the LAB 4a strain and other common gill isolates (4 Flavobacterium sp., a Flexibacter $\mathrm{sp}$. and Aeromonas hydrophilat, the assay proved specific for F. branchiophilum antigen. Adaption for field-collected samples is feasible, but will require further examination of the antigenic specificity, and re-optimization of the tissue sample concentration if gills from other species are to be tested. The ELISA is an achievable means of estimating the quantity of $F$. branchiophilum on the gills of large numbers of fish, and represents an important tool for bacterial gill disease research.
\end{abstract}

KEY WORDS: Flavobacterium branchiophilum . Enzyme-linked immunosorbent assay Bacterial gill disease $\cdot$ Gills

\section{INTRODUCTION}

Bacterial gill disease (BGD), one of the most common diseases of cultured salmonids in Ontario, Canada (Daoust \& Ferguson 1983, Speare \& Ferguson 1989), is caused by the Gram-negative filamentous organism Flavobacterium branchiophilum (Kimura et al. 1978, Wakabayashi et al. 1980, 1989, Farkas 1985, Heo et al. 1990, Ferguson et al. 1991, Ostland et al. 1994).

Recently, BGD was successfully reproduced in healthy rainbow trout Oncorhynchus mykiss fingerlings by bath exposure to Flavobacterium branchiophilum (Ferguson et al. 1991). The ability to reliably

- Present address: Maple Leaf Foods, Inc., Shur Gain Division, PO Box 279, 1 Salar Court, St George. New Brunswick, Canada EOG 2 YO reproduce $B G D$ creates many opportunities to investigate the pathogenesis and treatment of the disease, but such studies often require a method to accurately enumerate $F$. branchiophilum. The common method to quantify this bacterium is by culturing serial dilutions of a gill tissue homogenate (Ostland et al. 1990). However, the fastidious nature of $F$. branchiophilum results in poor recovery and inconsistent counts (Heo et al. 1990, Ostland et al. 1994). Furthermore, when it is necessary to sample a large number of fish, bacterial quantitation by culture becomes very labour intensive. Other methods for the detection and quantitation of $F$. branchiophilum include the indirect fluorescent antibody technique (Heo et al. 1990) and the observation of typical filamentous organisms on gill tissue by electron microscopy (Speare et al. 1991a, b), light microscopy or gill tissue whole mounts. These methods 
all have the disadvantages of being inaccurate, slow, and subjective. Therefore, a better method to estimate the number of $F$. branchiophilum on the gills is required.

The enzyme-linked immunosorbent assay (ELISA) offers several potential advantages in the detection and quantitation of antigen on the gills of rainbow trout. The ELISA is simple, sensitive and rapid; it facilitates quantitation of antigen; and the use of microtitre plates allows for the testing of a large number of samples (Voller et al. 1976, Voller \& Bidwell 1986, Arshkoosh \& Kaattari 1990, Kemeny 1991). The ELISA is widely used for the identification of other fish pathogens, including Aeromonas salmonicida (Smith 1981, Austin et al. 1986. Adams \& Thompson 1990), infectious pancreatic necrosis virus (Dixon \& Hill 1983), piscine rhabdoviruses (Dixon \& Hill 1984), Yersinia ruckerii (Austin et al. 1986), Renibacterium salmoninarum (Pascho \& Mulcahy 1987), viral hemorrhagic septicemia (Way \& Dixon 1988, Mourton et al. 1990, Sanz \& Coll 1992), infectious hematopoietic necrosis virus (Way \& Dixon 1988, Medina et al. 1992), and Vibrio anguillarum (Romestand et al. 1993). The numerous advantages and wide use of the assay in aquaculture prompted our attempt to develop an ELISA that could detect antigens of Flavobacterium branchiophilum.

This paper describes the development of an indirect ELISA which can be used to detect and enumerate Flavobacterium branchiophilum antigen on the gills of rainbow trout during experimental reproduction of BGD.

\section{MATERIALS AND METHODS}

In brief, Flavobacterium branchiophilum antigen was sought in samples of crude gill extract passively absorbed to a solid phase carrier (polystyrene microtitre plates). Antigen was detected by the sequential application of rabbit anti-F. branchiophilum serum, biotinylated goat anti-rabbit serum, enzyme-avidin conjugate (streptavidin peroxidase) and a chromogen [2,2' azino-(3 ethyl)-benzo-thiazoline-6-sulphonic acid]. The peroxidase-mediated color change was read on a spectrophotometric microplate reader when a standard reference sample obtained a fixed optical density (end point analysis).

Preparation of Flavobacterium branchiophilum. F. branchiophilum (LAB 4a) was used for production of antisera, bath exposure of rainbow trout, and for the preparation of samples of known bacterial concentration. The LAB 4 a strain of $F$ branchiophilum originated in a naturally occurring outbreak of BGD in brook trout Salvelinus fontinalis (Ferguson et al. 1991), and was subsequently identified on the basis of morphological, physiological, biochemical and antigenic properties (Ostland et al, 1994). A sample of the LAB $4 \mathrm{a}$ isolate (2nd passage) was stored in cytophaga broth (Anacker \& Ordal 1959) with $15 \%$ glycerol at $-70^{\circ} \mathrm{C}$ and served as the inoculum for subsequent cultures.

When required, the Flavobacterium branchiophilum ( $\mathrm{LAB} 4 \mathrm{a}$ ) stock was thawed at room temperature (RT), inoculated onto cytophaga agar and incubated aerobically at $18^{\circ} \mathrm{C}$. After $7 \mathrm{~d}, 3$ typical colonies were used to inoculate $100 \mathrm{ml}$ of cytophaga broth which was incubated at $18^{\circ} \mathrm{C}$ on a rotary shaker $(200 \mathrm{rpm})$ for $48 \mathrm{~h}$. A volume of $10 \mathrm{ml}$ of this culture was transferred to $1 \mathrm{l}$ flasks of cytophaga broth which were incubated at $18^{\circ} \mathrm{C}$ on a rotary shaker for another $48 \mathrm{~h}$. The bacteria were enumerated using a counting chamber (Collins \& Lyne 1976) and by plate counts of serial dilutions (Ostland et al. 1994).

Preparation and specificity of antisera for detection of Flavobacterium branchiophilum. Polyclonal anti- $F$. branchiophilum serum was prepared using methods previously described (Ostland et al. 1994). Briefly, the antiserum was produced in New Zealand white rabbits against a whole cell antigen preparation of $F$. branchiophilum (LAB 4a). The bacterial antigen was prepared from a 48 h 21 cytophaga broth culture of F. branchiophilum (LAB 4a) which was killed by the addition of $100 \mathrm{ml}$ of $0.5 \%(\mathrm{v} / \mathrm{v})$ formalinized phosphate buffered saline (PBS; $\mathrm{pH}$ 7.2). After overnight incubation at $10^{\circ} \mathrm{C}$ the cells were harvested by centrifugation and resuspended in $25 \mathrm{ml}$ of formalinized PBS. Following this, the cells were homogenized with an equal volume of Freund's incomplete adjuvant One $\mathrm{ml}$ of the homogenate was injected subcutaneously into the rabbits. Blood was collected following 4 antigen injections at 2 wk intervals, and the serum was separated following overnight clotting at $4{ }^{\circ} \mathrm{C}$. The serum was heat-inactivated $\left(56^{\circ} \mathrm{C}\right.$ for $\left.30 \mathrm{~min}\right)$ and the titre (1:2048) was determined by whole-cell microtitre agglutination.

The antigenic specificity of the rabbit anti-Flavobacterium branchiophilum polyclonal serum was evaluated by comparing the ELISA cross reactivity of $F$. branchiophilum (LAB 4a) with $F$. branchiophilum recovered from BGD in salmonids in Japan (ATCC 35035; American Type Culture Collection, Rockville, MD, USA), Aeromonas hydrophila (ATCC 7966) and other common gill isolates. The other isolates were recovered from clinical cases of BGD submitted to the Fish Pathology Laboratory. These included 2 nonfilamentous Flavobacterium sp. recovered from separate cases of salmonid BGD (B102-87, B201-87 A1), a nonfilamentous Flavobacterium sp. recovered from goldfish Carassias auratus with BGD (B315-86), a nonfilamentous Flavobacterium sp. recovered from the same 
BGD outbreak as the LAB 4 a strain (B142-90), and a Flexibacter sp. recovered from a case of $\mathrm{BGD}$ in brook trout Salvelinus fontinalis (B201-87 A2). The bacterial isolates recovered from clinical cases were identified using the methods described by Ostland (1989). Whole-cell suspensions of the various isolates in PBS were enumerated using a counting chamber (Collins \& Lyne 1976). The samples were then diluted in coating buffer to yield final dilutions ranging from $1 \times 10^{2}$ to $1 \times 10^{7}$ cells $\mathrm{ml}^{-1}$, coated on a microtitre plate and processed for the ELISA as described below. Results were compared using bacterial concentrations of $1 \times$ $10^{6}$ cells $\mathrm{ml}^{-1}$, as that dilution produced the highest ELISA optical density (OD).

Preparation of test samples for solid phase coating. Infected gill samples, spiked gill samples and LAB $4 \mathrm{a}$ whole cell samples were used to develop the assay. In the case of infected gill samples, the diseased fish were killed with an overdose of MS 222 (tricaine methanesulfonate; Crescent Research Chemicals, Phoenix, AZ, USA). Immediately following euthanasia, the first 3 gill arches were removed from the right side of fish and were placed in preweighed vials containing $1 \mathrm{ml}$ of distilled water plus $0.05 \%$ Tween 20 . Vials were weighed to determine the quantity of gill tissue and then frozen at $-70^{\circ} \mathrm{C}$ until further processing. At time of processing the samples were thawed at RT and placed on ice. Each sample was homogenized for $30 \mathrm{~s}$ (Pro 200 Homogenizer; Pro Scientific, Monroe, CT) and sonicated on ice for $30 \mathrm{~s}$ (Branson Sonifier 250; Branson Ultrasonic, Danbury, CT, USA). The sonicate was centrifuged at $13000 \times g$ for $5 \mathrm{~min}$ and the supernatant stored at $-70^{\circ} \mathrm{C}$ until used to coat the solid phase. The tissue concentration of the samples is expressed in terms of the wet weight of gill tissue present. The gill samples processed as described above are hereafter referred to as crude gill extracts.

Whole cell samples were prepared from a $48 \mathrm{~h}$ cytophaga broth culture of Flavobacterium branchiophilum (LAB 4a) which was washed 3 times in distilled water containing $0.05 \%$ Tween 20 by 5 min centrifugation at $13000 \times g$, followed by resuspension of the cells in $10 \mathrm{ml}$ of distilled water containing $0.05 \%$ Tween 20. Individual samples were prepared by dilution of an aliquot of the whole-cell preparation to the desired concentration in distilled water containing $0.05 \%$ Tween 20 . The samples were then homogenized, sonicated and centrifuged in the same manner as infected gill tissue. These samples are subsequently referred to as the $\mathrm{LAB} 4 \mathrm{a}$ whole-cell sonicates.

Spiked gill samples were prepared using gill tissue collected from 19 normal rainbow trout (mean weight $75 \mathrm{~g})$ which had no history of BGD, no evidence of filamentous bacteria on gill whole mounts and no histopathological lesions. The tissues were collected and processed in a manner similar to that of infected gill tissue. Following homogenization, the samples were divided and mixed with various amounts of washed whole cell Flavobacterium branchiophilum $\left(10^{2}\right.$ to $10^{9}$ cells $\mathrm{g}^{-1}$ gill tissue). The samples were then homogenized, sonicated and centrifuged in the same manner as infected gill tissue samples.

ELISA protocol. Polystyrene microtitre plates (Immulon IV MicroElisa plates; Dynatech Laboratories, Chantilly, VA, USA) were coated with either infected crude gill extract, spiked crude gill extract, or LAB 4a whole cell sonicate. Tissue samples were diluted to a concentration of $100 \mu \mathrm{g}$ gill tissue $\mathrm{ml}^{-1}$ in carbonatebicarbonate coating buffer ( $\mathrm{pH}$ 9.6; Voller \& Bidwell 1986) and $100 \mu \mathrm{l}$ was added to each well. The LAB $4 \mathrm{a}$ whole-cell sonicates were diluted to the desired concentration in the carbonate-bicarbonate coating buffer, and $100 \mu l$ was added to the appropriate wells. Controls on each plate included a strong (OD $\sim 0.800$ ), intermediate and weak positive (OD 0.200) infected gill tissue sample, a normal gill tissue sample and a blank well (did not receive a tissue sample but received all other reagents). All samples were tested in duplicate or quadruplicate. The plates were incubated at $4^{\circ} \mathrm{C}$ overnight.

Plates were washed 5 times with PBS/Tween (PBS containing $0.05 \%$ Tween $20 ; 200 \mu$ well ${ }^{-1}$ ), blocked (3\% bovine serum albumin in PBS containing $0.02 \%$ sodium azide; $120 \mu \mathrm{l}_{\text {well }}^{-1}$ ), incubated at RT for $1 \mathrm{~h}$ and then rewashed with PBS/Tween. Similarly, rabbit anti-Flavobacterium branchiophilum (1:1750 in PBS/ Tween; $90 \mu \mathrm{l}$ well-1), biotin conjugated goat-antirabbit (Calbiochem; San Diego, CA, USA; 1:500 in PBS/Tween) and streptavidin peroxidase (Kirkegard \& Perry Laboratories, Gaithersburg, MD: 1:2000 in PBS/ Tween) were added sequentially. Each step was separated by a 1 h RT incubation followed by a wash. Wells were developed with ABTS $\left[2,2^{\prime}\right.$ azino-(3 ethyl)-benzothiazoline-6-sulphonic acid, Kirkegard Perry Laboratories; $100 \mu \mathrm{l}$ well $^{-1}$ ] and then read at $405 \mathrm{~nm}$ and $630 \mathrm{~nm}$ (Microplate Autoreader EL311, Bio-tek Instruments, Winooski, VT, USA). The dual wavelength reading was used in order to eliminate the effect of random light scattering and provide a more accurate measure of the absorbance of each well at $405 \mathrm{~nm}$. The exact time of reading was determined by monitoring the development of a sample standard included on each plate, and reading the plate when the standard reached a fixed $O D(0.800)$.

Development of the ELISA protocol. The ELISA protocol described above was developed by the systematic variation of each step. The optimal concentration of crude gill extract was established by checkerboard titration of various tissue concentrations of both infected and spiked gill samples against dilutions of 
the rabbit anti-Flavobacterium branchiophilum. The well surfaces were coated with crude extracts of infected, spiked and normal gill samples diluted in carbonate-bicarbonate coating buffer to concentrations ranging from $10 \mathrm{mg}$ to $1 \mu \mathrm{g}$ of gill tissue $\mathrm{ml}^{-1}$. The plates were processed for the ELISA using dilutions of rabbit anti-F. branchiophilum ranging from 1:50 to 1:2000. The optimum tissue concentration was chosen as that which produced the greatest contrast between negative and positive sample ODs, with a minimum of 0.800 for positive samples and a maximum of 0.100 for the negative samples (Voller \& Bidwell 1986).

The preparation of the crude gill extract was also optimized with respect to the effect of the duration of tissue homogenization, sonication and clarification by centrifugation.

The optimal reagent dilutions were also determined by checkerboard titration. As described above, the rabbit anti-Flavobacterium branchiophilum dilution was optimized by titration of various dilutions against varying sample tissue concentrations. The dilution of goat anti-rabbit was determined by checkerboard titration against varying dilutions of streptavidin peroxidase. The range of the secondary antibody (biotinylated goat-anti-rabbit) and the enzyme conjugate (streptavidin peroxidase) titrations were 1:500 to 1:2000. A variety of blocking solutions, including $3 \%$ bovine serum albumin in PBS, $3 \%$ Tween 20 in PBS, $5 \%$ skim milk in PBS, and $0.05 \%$ Tween 20 in PBS, were also systematically compared. Again, the optimal dilution or reagent was chosen as that which produced the greatest contrast between negative and positive sample OD-values, with a minimum of 0.800 for positive samples and a maximum of 0.100 for the negative samples (Voller \& Bidwell 1986).

Determination of quantitative ability and the detection threshold. The detection threshold and quantitative ability of the assay were determined using samples containing a known quantity of bacteria (Flavobacterium branchiophilum LAB $4 \mathrm{a}$ whole cell samples and spiked gill samples), as well as experimentally infected gill samples. Infected gill samples were also used to correlate ELISA absorbance with colony forming units per $g$ of gill tissue (CFU $\mathrm{g}^{-1}$ ). LAB 4 a whole cell samples were prepared by diluting whole cell sonicates, prepared as described above, to various concentrations in coating buffer. The wholecell samples were coated on the microtitre plate as described above. Spiked gill samples were prepared and coated on the plate as described above.

Infected gill tissues were from 2 sources. The first source was a 'laboratory pool' of infected gill samples. These tissues were collected during earlier experiments unrelated to the development of the ELISA. In those experiments rainbow trout were exposed to Flavobacterium branchiophilum by bath challenge. Following the bath challenge, estimation of the number of $F$ branchiophilum on the gills was attempted by colony counts on serial dilutions of the gill tissue homogenate. The methods of bath challenge and gill tissue sampling were similar to those described in this paper. The methods of sample processing, plate culture and quantification of viable F. branchiophilum were as previously described (Ostland et al. 1990). From the pool of samples, 9 infected and 11 healthy gill samples were chosen to be processed for the ELISA. The choice of samples was based on the criteria of successful bacterial culture and the quantity of bacteria recovered. The widest possible range of bacterial recovery was sought. These samples were processed for the ELISA as described above.

The second source of infected gill tissue was obtained from a graded concentration bath challenge of rainbow trout. Twelve 1 l tanks were each stocked with fifteen $4 \mathrm{~g}$ rainbow trout. The flow rate in each tank was adjusted to $8 \mathrm{l} \mathrm{h}^{-1}$ and the water temperature was maintained at $14^{\circ} \mathrm{C}$. The challenge was performed by adding different volumes of a $48 \mathrm{~h}$ cytophaga broth culture of Flavobacterium branchiophilum to each tank. Tanks 1 through 11 received 1, 5, 10, 50, 100, 150, $200,250,300,400$ and $475 \mathrm{ml}$ of the broth culture, respectively (plus a volume of sterile broth sufficient to bring the total volume to $500 \mathrm{ml}$ for each tank). The resulting bacterial concentrations in the baths ranged from $1.73 \times 10^{3}$ to $1.64 \times 10^{6} \mathrm{CFU} \mathrm{ml} \mathrm{m}^{-1}$ of tank water. Tank 12 received $500 \mathrm{ml}$ of sterile cytophaga broth. Water flow to each tank was turned off immediately prior to exposure, but aeration was maintained. After $1 \mathrm{~h}$ water flow was restored, and $1.5 \mathrm{~h}$ post-exposure the fish in each tank were killed with an overdose of MS222. Gill arches were taken from all fish in each tank and processed for the ELISA as described above.

In order to correlate ELISA absorbance with colony forming units per $g$ of gill tissue $\left(\mathrm{CFU} \mathrm{g}{ }^{-1}\right), 9$ fish were collected from each of 7 tanks for bacterial culture following the challenge. The tanks receiving 475,300 , $250,200,100$, and $5 \mathrm{ml}$ of the $48 \mathrm{~h}$ cytophaga broth culture of Flavobacterium branchiophilum, as well as the negative control tank, were sampled. For each fish the first 3 gill arches from the left side were aseptically removed, placed in preweighed vials containing $5 \mathrm{ml}$ of sterile distilled water and immediately processed. The methods of processing, plate culture and quantitation of viable $F$. branchiophilum were as previously described (Ostland et al. 1990)

Precision, reproducibility and parallelism. The intra-assay variation (precision) of the Flavobacterium branchiophilum ELISA was determined by examining the variability of the results of repeated analyses $(n=4)$ 
of individual infected gill samples $(n=10)$ in a single assay (McLaren et al. 1981, Kemeny 1991). The gill samples used were derived from the graded concentration bath challenge described above.

The inter-assay variation (reproducibility) of the Flavobacterium branchiophilum ELISA was measured as the agreement among the results of repeated analyses of 11 infected gill samples, ranging from negative to strongly positive, on 4 different test days (McLaren et al. 1981, Kemeny 1991). The gill samples used were also derived from the graded concentration bath challenge described above.

Four infected gill samples which produced high $(1.0$ to 1.5) ELISA absorbances (405 nm) at tissue concentrations of $100 \mathrm{\mu g} \mathrm{ml}^{-1}$ coating buffer were used to demonstrate parallelism. These samples were diluted 1:4 to $1: 8$ in coating buffer, coated on microtitre plates as described above, and processed for the Flavobacterium branchiophilum antigen detection ELISA.

\section{RESULTS}

\section{Antigenic specificity}

The polyclonal rabbit anti-Flavobacterium branchiophilum serum was specific, based on comparison of the ELISA absorbances of F. branchiophilum (LAB 4a), F. branchiophilum (ATCC 35035) and other bacteria commonly isolated from the gill (Table 1). Both strains of $F$. branchiophilum produced very high readings, while all but one of the other gill isolates produced negative readings. One nonfilamentous Flavobacterium sp. produced a low positive reading.

Table 1. Flavobacterium branchiophilum. Antigenic specificity of the antigen detection ELISA using polyclonal rabbit anti-F branchiophilum (LAB 4a) serum. Specificity was evaluated by comparing the ELISA absorbance values ( $405 \mathrm{~nm}$ ) obtained with whole-cell sonicates of the LAB $4 \mathrm{a}$ strain, the type strain (ATCC 35033), and 6 other common gill isolates. An absorbance $>0.088$ is positive (twice mean OD of negative control). ATCC American Type Culture Collection; FPL: Fish Pathology Laboratory isolate Brook trout: Salvelinus fontinalis; Goldfish: Carassias auratus; rainbow trout: Oncorhynchus mykiss

\begin{tabular}{|llll|}
\hline $\left.\begin{array}{llll|}\text { Organism } \\
\left(10^{6} \text { cells ml }\right.\end{array}{ }^{-1}\right)$ & Strain & Source & Absorbance \\
\hline F. branchiophilum & LAB 4a & Brook trout & 2.457 \\
F. branchiophilum & ATCC 35035 & ATCC & 2.545 \\
Aeromonas hydrophila & ATCC 7966 & ATCC & 0.038 \\
Flavobacterium sp. & FPL B315-86 & Goldfish & 0.024 \\
Flavobacterium sp. & FPL B102-87 & Rainbow trout & 0.173 \\
Flavobacterium sp. & FPL B201-87 A1 & Brook trout & 0.013 \\
Flexibactersp. & FPL B201-87 A2 & Brook trout & 0.025 \\
Flavobacterium sp. & FPL B142-90 & Brook trout & 0.041 \\
\hline
\end{tabular}

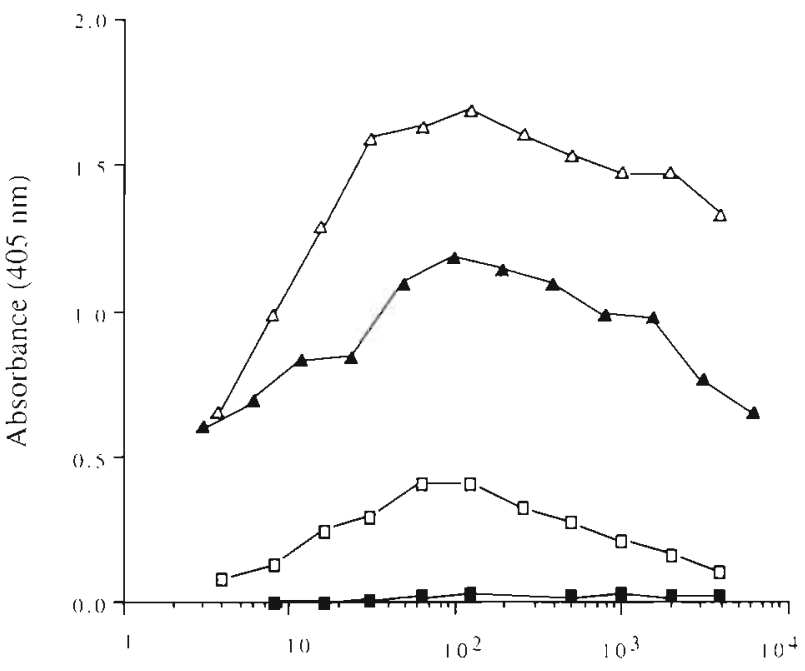

Gill tissue concentration $\left(\mu \mathrm{g} \mathrm{ml^{-1 }}\right)$

Fig. 1. Flavobacterium branchiophilum. Effect of gill tissue concentration on antigen detection using the ELISA. The ELISA absorbance of graded concentration of infected, spiked and normal gill extracts are compared. ( $\Delta)$ Spiked gill $1\left(10^{5}\right.$ cells $100 \mathrm{\mu g}^{-1} \mathrm{gill}$ tissue by direct microscopic count); (ㅁ) spiked gill 2 $\left(10^{4}\right.$ cells $100 \mathrm{\mu g}^{-1} \mathrm{gill}$ tissue by direct microscopic count); (४) infected gill (direct microscopic count not made); (-) normal gill

\section{Optimal antigen concentration, reagent dilutions and tissue processing technique}

The maximum absorbance occurred when samples of gill tissue were diluted to approximately $100 \mu \mathrm{g} \mathrm{ml}^{-1}$ (Fig. 1). This effect was observed in both infected and spiked gill tissue, and was independent of the quantity of Flavobacterium branchiophilum present in the sample. Therefore, $100 \mu \mathrm{g} \mathrm{ml}^{-1}$ was chosen as the optimal tissue concentration for coating microtitre plate well surfaces.

The optimal reagent dilutions were chosen as those which produced the great est contrast between positive and negative sample readings while still producing low background OD (i.e. negative sample $<0.100)$. The optimal dilutions for rabbit anti-Flavobacterium branchiophilum serum, biotinylated goat anti-rabbit, and streptavidin peroxidase were 1:1750, 1:500 and 1:2000, respectively. The optimal blocking solution, 3\% BSA in PBS, was slightly preferable to the others tested. Homogenization and sonication of the tissue samples resulted in higher readings for positive samples without increasing the readings of negative samples. Clarification by centrifugation was found to moderately reduce the intra-assay and inter-assay variation. 


\section{Detection threshold}

The cut-off OD for detection of a positive sample was established as twice the mean absorbance of negative samples. This cut-off value was chosen because the greater of either twice the mean absorbance of negative samples, or the mean absorbance of negative samples plus 3 standard deviations of the mean, represented a cut-off value with a $99 \%$ probability that a positive sample would yield a higher absorbance value (McLaren et al. 1981, Kemeny 1991, Medina et al. 1992). Analysis of gill extracts from 34 normal fish (Tables $2 \& 3$ ), as well as from 126 normal fish tested in subsequent experiments (D. MacPhee unpubl.), demonstrated that the SD values associated with the mean absorbance for normal gills was small. Because 3 times the SD value did not exceed the mean absorbance for normal gills, twice the mean absorbance for normal gills became the positive cut-off point. In order to reduce the possibility of interassay variation resulting in false positives or false negatives, the cut-off point was specific for each individual assay and was based on the OD of negative samples included each assay.

The limit of detection of the ELISA for whole cell Flavobacterium branchiophilum was ca 500 bacteria $\mathrm{ml}^{-1}$ (i.e. 50 bacteria well ${ }^{-1}$ ) (Table 2). Using spiked gill samples the detection limit was ca 1000 bacteria $100 \mathrm{\mu g}^{-1}$ of gill tissue (i.e. 100 bacteria well $^{-1}$ ) (Table 2).

The detection threshold of the ELISA was also compared to Flavobacterium branchiophilum detection by bacterial culture (Table 3). Of the 54 infected fish cultured following the graded concentration bath challenge, bacterial recovery was successful in 19. The range of the bacterial counts obtained was $2.68 \times 10^{4}$ to $1.76 \times 10^{7} \mathrm{CFU} \mathrm{g}^{-1}$ of gill tissue. All fish produced positive ELISA readings except one which had a bacterial load $\left(4.79 \times 10^{4} \mathrm{CFU} \mathrm{g}^{-1}\right)$ near the limit detectable by culture. However, the fish which had the lowest bacterial load $\left(2.68 \times 10^{4} \mathrm{CFU} \mathrm{g} \mathrm{g}^{-1}\right)$ produced a positive ELISA reading (Table 3 ). Of the 9 fish chosen from the 'laboratory pool', the range of bacterial recovery was $4.97 \times 10^{6}$ to $26.5 \times 10^{6} \mathrm{CFU} \mathrm{g}^{-1}$ gill tissue. The ELISA produced medium to strongly positive readings for all 9 fish examined (Table 3 ).

\section{Quantitation of Flavobacterium branchiophilum antigen}

Comparison of the ELISA absorbance with the number of Flavobacterium branchiophilum applied to the plate as a whole cell preparation produced a typical dose response curve (Fig. 2A) with a plateau at approximately 80000 cells $\mathrm{ml}^{-1}$. Spiked gill samples produced a similar dose response curve (Fig. 2B).

Comparison of the mean ELISA absorbance with the concentration of bacteria in the graded concentration bath challenge produced a linear relationship between exposure concentration and absorbance (Fig. 3). However, bacterial culture results for the challenge were

Table 2. Flavobacterium branchiophilum. Detection threshold of the antigen detection ELISA, evaluated using 3 whole-cell preparations of $F$. branchiophilum (Fb-1, $-2,-3 ; 4$ replicates) and 4 preparations of normal gill tissue spiked with known concentrations of the organisms ( $\mathrm{S}-1,-2,-3,-4 ; 2$ replicates). SD-R: SD of replicates of 1 sample; SD-S: SD of a number of different samples: $\mathrm{P} / \mathrm{N}$ : positive/negative ratio; $+\mathrm{P} / \mathrm{N} \geq 2$

\begin{tabular}{|c|c|c|c|c|c|c|}
\hline Preparation & $\begin{array}{c}\text { Concentration } \\
\text { (cells } \mathrm{ml}^{-1} \text { ) }\end{array}$ & Mean OD & $S D-R$ & $S D-S$ & $\mathrm{P} / \mathrm{N}$ & Detection \\
\hline \multirow[t]{5}{*}{$\mathrm{Fb}-1$} & 1000000 & 1.235 & 0.027 & & 21.7 & + \\
\hline & 100000 & 1.229 & 0.032 & & 21.6 & + \\
\hline & 10000 & 0.881 & 0.110 & & 15.5 & + \\
\hline & 1000 & 0.141 & 0.041 & & 2.5 & + \\
\hline & 0 & 0.057 & 0.001 & & 1.0 & - \\
\hline \multirow[t]{5}{*}{$\mathrm{Fb}-2$} & 10000 & 0.752 & 0.048 & & 28.8 & + \\
\hline & 5000 & 0.561 & 0.007 & & 22.4 & + \\
\hline & 1000 & 0.096 & 0.013 & & 3.8 & + \\
\hline & 500 & 0.052 & 0.016 & & 2.1 & + \\
\hline & 0 & 0.025 & 0.003 & & 1.0 & - \\
\hline \multirow[t]{5}{*}{$\mathrm{Fb}-3$} & 10000 & 1.058 & 0.079 & & 20.0 & + \\
\hline & 5000 & 0.926 & 0.015 & & 8.4 & + \\
\hline & 1000 & 0.178 & 0.032 & & 3.4 & + \\
\hline & 500 & 0.108 & 0.008 & & 2.1 & + \\
\hline & 0 & 0.051 & 0.001 & & 1.0 & - \\
\hline \multirow[t]{5}{*}{ S-1 } & 100000 & 1.568 & 0.016 & & 39.2 & + \\
\hline & 10000 & 0.460 & 0.047 & & 11.5 & + \\
\hline & 1000 & 0.090 & 0.003 & & 2.2 & + \\
\hline & 100 & 0.070 & 0.008 & & 1.7 & - \\
\hline & 0 & 0.040 & & $0.013^{\mathrm{a}}$ & 1.0 & - \\
\hline \multirow[t]{5}{*}{ S-2 } & 100000 & 1.656 & 0.040 & & 72.0 & + \\
\hline & 10000 & 0.410 & 0.006 & & 17.8 & + \\
\hline & 1000 & 0.051 & 0.005 & & 2.2 & + \\
\hline & 100 & 0.025 & 0.004 & & 1.1 & - \\
\hline & 0 & 0.023 & 0.004 & & 1.0 & - \\
\hline \multirow[t]{5}{*}{ S-3 } & 100000 & 1.374 & 0.048 & & 49.1 & + \\
\hline & 10000 & 0.450 & 0.066 & & 16.1 & + \\
\hline & 1000 & 0.076 & 0.004 & & 2.7 & + \\
\hline & 100 & 0.033 & 0.001 & & 1.2 & - \\
\hline & 0 & 0.028 & 0.000 & & 1.0 & - \\
\hline \multirow[t]{4}{*}{$S-4$} & 5000 & 0.250 & 0.144 & & 4.8 & + \\
\hline & 500 & 0.063 & 0.012 & & 1.2 & - \\
\hline & 50 & 0.055 & 0.055 & & 1.1 & - \\
\hline & 0 & 0.052 & & $0.012^{b}$ & 1.0 & - \\
\hline
\end{tabular}


Table 3. Flavobacterium branchiophilum. Comparison of the plate count estimation of bacteria on the gills to the mean ELISA absorbance of crude gill extract in experimentally infected fish (4 replicates). Samples A.1 to A.19 and 'Normal gill 1' were from the bath exposure of rainbow trout Oncorhynchus mykiss to graded concentrations of F. branchiophilum. Samples B1 to B9 and 'Normal gill 2' were selected from the 'laboratory pool' of gill samples. SD-R: SD of replicates of 1 sample; SD-S: of a number of different samples; $\mathrm{P} / \mathrm{N}$ : positive/ negative ratio; $+: \mathrm{P} / \mathrm{N} \geq 2$

\begin{tabular}{|c|c|c|c|c|c|c|}
\hline Sample & $\mathrm{CFU} \times 10^{5} \mathrm{~g}^{-1}$ & Mean OD & $\mathrm{SD}-\mathrm{R}$ & SD-S & $\mathrm{P} / \mathrm{N}$ & Detection \\
\hline $\mathrm{A} 1$ & 0.268 & 0.807 & 0.076 & & 3.5 & + \\
\hline A2 & 0.479 & 0.279 & 0.015 & & 1.2 & - \\
\hline A 3 & 0.893 & 0.526 & 0.062 & & 2.3 & + \\
\hline A.4 & 1.24 & 0.560 & 0.011 & & 2.4 & + \\
\hline A5 & 3.1 & 0.902 & 0.010 & & 3.9 & + \\
\hline A6 6 & 4.6 & 0.618 & 0.061 & & 2.7 & + \\
\hline A.7 & 5.4 & 0.606 & 0.064 & & 2.6 & + \\
\hline A.8 & 11.9 & 0.843 & 0.156 & & 3.7 & + \\
\hline A9 & 15.5 & 0.902 & 0.010 & & 3.9 & + \\
\hline A.10 & 17.2 & 0.530 & 0.043 & & 2.3 & + \\
\hline A 11 & 17.8 & 0.731 & 0.010 & & 3.2 & + \\
\hline $\mathrm{A} 12$ & 23.1 & 0.593 & 0.028 & & 2.6 & + \\
\hline A.13 & 23.6 & 1.227 & 0.004 & & 5.3 & + \\
\hline A.14 & 42.3 & 0.664 & 0.064 & & 2.9 & + \\
\hline A15 & 46.3 & 0.865 & 0.001 & & 3.8 & + \\
\hline A 16 & 50.2 & 0.630 & 0.059 & & 2.7 & + \\
\hline A 17 & 55.3 & 0.780 & 0.021 & & 3.4 & + \\
\hline A 18 & 133.0 & 0.939 & 0.075 & & 4.1 & + \\
\hline A.19 & 176.0 & 1.071 & 0.004 & & 4.7 & + \\
\hline Normal gill & 110.0 & 0.230 & & $0.022^{\mathrm{a}}$ & 1.0 & - \\
\hline B1 & 13.9 & 0.407 & 0.013 & & 7.3 & + \\
\hline B2 & 30.9 & 0.586 & 0.058 & & 10.5 & + \\
\hline B3 & 46.8 & 0.553 & 0.028 & & 9.9 & + \\
\hline B4 & 48.2 & 0.371 & 0.044 & & 6.6 & + \\
\hline B5 & 49.7 & 0.828 & 0.025 & & 14.8 & + \\
\hline$B 6$ & 122.8 & 0.399 & 0.059 & & 7.1 & + \\
\hline B7 & 176.1 & 0.415 & 0.001 & & 7.4 & + \\
\hline B8 & 231.7 & 0.508 & 0.012 & & 9.1 & + \\
\hline B9 & 264.9 & 1.173 & 0.039 & & 20.9 & + \\
\hline Normal gill & 120.0 & 0.056 & & $0.010^{\mathrm{b}}$ & 1 & - \\
\hline
\end{tabular}

inconsistent, and there was poor correlation between the concentration of Flavobactenum branchiophilum cells in the bath and the number of $F$. branchiophilum recovered from the gills (Fig. 4).

\section{Precision, reproducibility and parallelism}

Under routine assay conditions, the intra-assay variation (precision) was less than $\pm 10 \%$ of the mean OD of replicates of an individual sample (Table 4). Expressed as the coefficient of variation $(\mathrm{CV}=\mathrm{SD} /$ mean $\times 100)$, there was a range from $1.9 \%$ for a strongly positive sample, up to $9.7 \%$ for a negative or weakly positive sample, with an mean of $6.7 \%$.

Comparison of the mean OD of samples on different test days (11 samples performed in quadruplicate in each of 4 assays) demonstrated inter-assay variation (reproducibility) ranging from 3.8 to $11.3 \%(\mathrm{CV})$, with an overall mean of $8.1 \%$ (Table 5).

Dilutions of 4 infected gill samples which were strongly positive at the normal tissue concentration for solid phase coating $\left(100 \mu \mathrm{g} \mathrm{ml} \mathrm{m}^{-1}\right)$ produced curves parallel to the standard curve when further diluted $(1: 4$ to $1: 8)$ in coating buffer and processed for the ELISA. (Fig. 5).
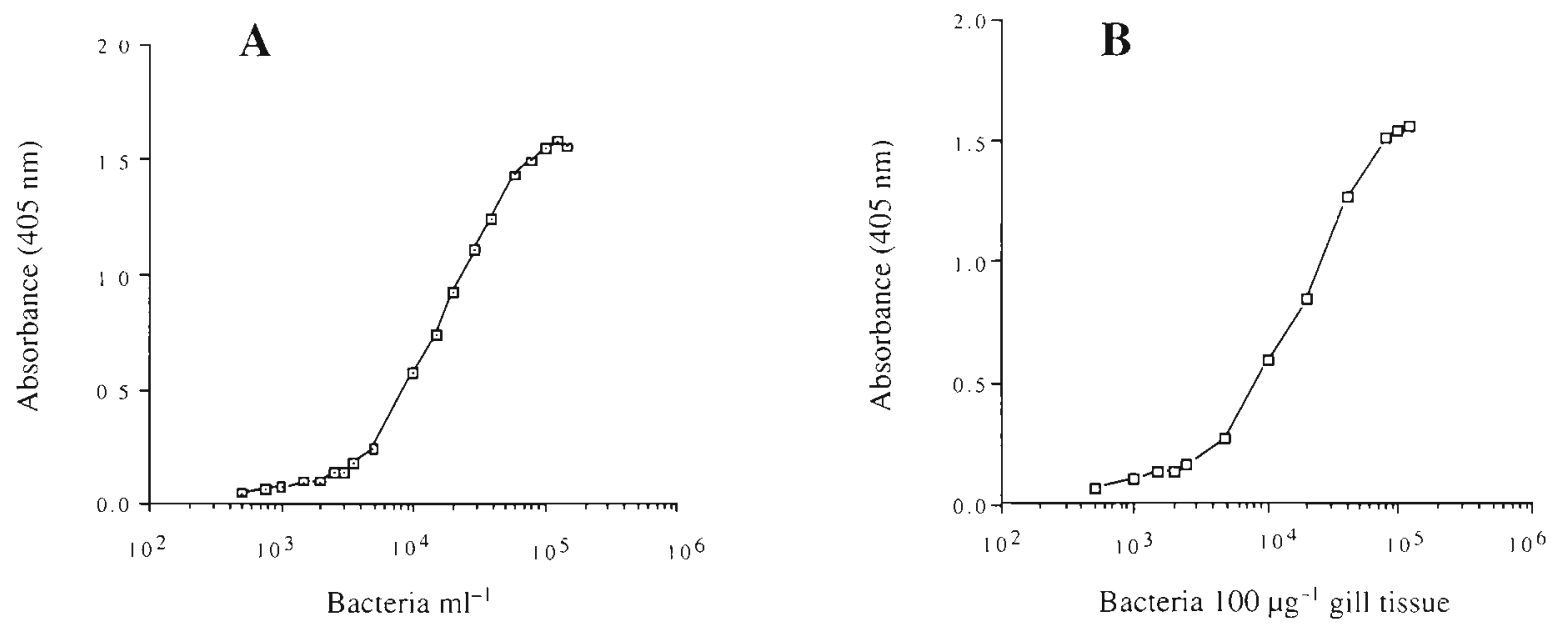

Fig. 2. Flavobacterium branchiophilum. Correlation between the amount of bacteria and the absorbance produced by the antigen detection ELISA. Whole-cell sonicates (A) and crude extracts of normal gills spiked with known quantities of $F$. branchiophilum (B) were tested. Semi-logarithmic plot 


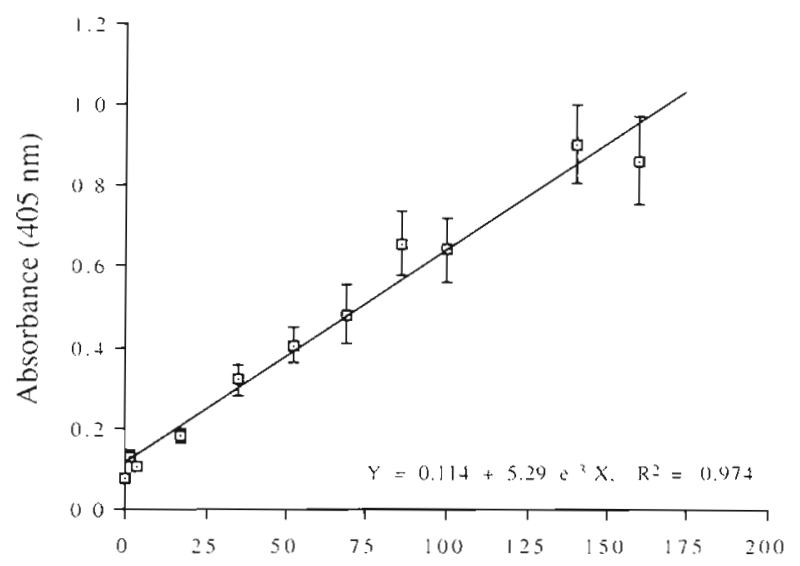

Bath challenge concentration $\left(\mathrm{CFU} \times 10^{4} \mathrm{ml}^{-1} \mathrm{H}_{2} \mathrm{O}\right)$

Fig. 3. Flavobacterium branchiophilum. Correlation between the concentration of bacteria in the bath used to challenge rainbow trout Oncorhynchus mykiss fingerling and the absorbance $[405 \mathrm{~nm} \pm \mathrm{SE}, \mathrm{n}=15$ ) of crude gill extracts processed for $F$. branchiophilum antigen detection ELISA. Linear plot

\section{DISCUSSION}

One method by which an ELISA may be used to quantify antigen is to demonstrate that the absorbance is proportional to the amount of antigen present in the sample (end point analysis). Having done that, a set of standards must be prepared and included in each assay (Kemeny 1991). Our results demonstrated that graded concentrations of Flavobacterium branchiophilum cells, and graded concentrations of the bacterum mixed with normal gill tissue (spiked gill samples), each produced absorbances proportional

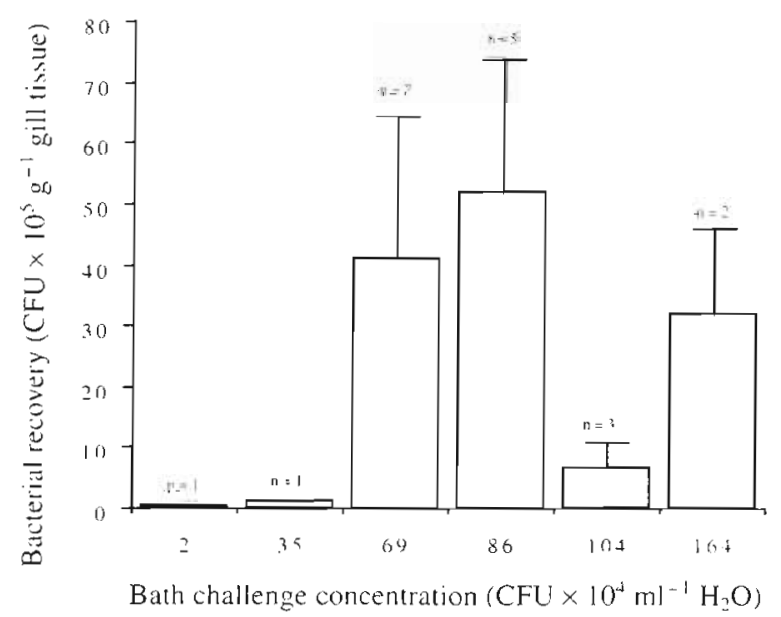

Fig. 4 Flavobacterium branchiophilum. Comparuson of the plate count estimation of the number ( \pm SE) of bacteria on gills to the concentration of bacteria in the bath used. to challenge rainbow trout Oncorhynchus mykiss fingerlings. n: number of culture positive fish in each group
Table 4. Flavobacterium branchiophilum. The intra-assay variation of the antigen detection ELISA, determined by the mean coefficient of variation in absorbance (405 nm) among 4 replicates of individual infected gill samples in a single assay. Eleven gill samples varying from normal to strongly positive were compared

\begin{tabular}{|cccccc|}
\hline Sample & Minimum & Maximum & Mean & SD & CV \\
\hline 1 & 0.089 & 0.106 & 0.099 & 0.007 & 7.3 \\
2 & 0.090 & 0.101 & 0.096 & 0.006 & 5.8 \\
3 & 0.192 & 0.210 & 0.201 & 0.008 & 3.8 \\
4 & 0.269 & 0.325 & 0.307 & 0.026 & 8.4 \\
5 & 0.360 & 0.433 & 0.398 & 0.039 & 9.7 \\
6 & 0.423 & 0.499 & 0.463 & 0.038 & 8.3 \\
7 & 0.542 & 0.638 & 0.593 & 0.042 & 7.1 \\
8 & 0.604 & 0.671 & 0.636 & 0.033 & 5.2 \\
9 & 0.742 & 0.873 & 0.829 & 0.060 & 7.3 \\
10 & 0.784 & 0.820 & 0.804 & 0.015 & 1.9 \\
Normal gill & 0.074 & 0.089 & 0.081 & 0.007 & 8.5 \\
& & \multicolumn{5}{c}{ Overall mean CV: } & 6.7 \\
\hline
\end{tabular}

to antigen quantity (Fig. 2). To ensure that this relationship also applied to infected gills, healthy fish were exposed to graded concentrations of the bacterium. The assumption was that bath exposure of healthy fish to different quantities of $F$. branchiophilum would result in bacterial attachment that was proportional to the concentration of the pathogen in the water. As anticipated, the ELISA results demonstrated a linear relationship between concentration of the bacterium in the bath and the OD (Fig. 3). Therefore, we concluded that the ELISA could be used as an end point assay to estimate the quantity of $F$. branchiophilum on the gills of rainbow trout, and that a reference curve could be constructed using either infected gills, spiked gills or whole-cell bacteria. However, other aspects of the test such as sample variation and its specificity also required consideration.

The units in which the estimation of bacterial quantity is expressed are important. An attempt was made to correlate colony counts of bacteria cultured from gills with the ELISA estimate of bacteria on the gills of fish exposed to graded bath challenges of Flavobacterium branchiophilum. Unfortunately, the poor success of bacterial culture (9 of 54 fish cultured), and the poor correlation between number of bacteria cultured and bacterial concentrations in the bath (Fig. 4), did not allow for successful comparisons. Similarly, the ELISA results with fish from the 'laboratory pool' of infected gill tissues (Table 3) were poorly correlated with colony counts of bacteria cultured from those samples. The disparity between bacterial culture and ELISA results may be attributed to the fastidious nature of the organism (Ostland et al. 1994), the detection of both viable and nonviable cells by the ELISA, or aggregation of cells of the bacterium which results 
Table 5. Flavobacterium branchiophilum. The inter-assay variation of the antigen detection ELISA, determined by the mean coefficient of variation in absorbance of individual infected gill samples on different test days. Four replicates of each sample were performed on each test day. Eleven gill samples varying from normal to strongly positive were compared

\begin{tabular}{|ccccccccr|}
\hline \multirow{2}{*}{ Sample } & \multicolumn{9}{c}{ Mean sample abs. on each test day } & Mean & SE & CV \\
& 1 & 2 & 3 & 4 & & & \\
\hline 1 & 0.095 & 0.101 & 0.106 & 0.081 & 0.096 & 0.011 & 11.3 \\
2 & 0.094 & 0.101 & 0.095 & 0.093 & 0.096 & 0.004 & 3.8 \\
3 & 0.174 & 0.185 & 0.174 & 0.154 & 0.172 & 0.013 & 7.5 \\
4 & 0.288 & 0.324 & 0.317 & 0.251 & 0.295 & 0.033 & 11.3 \\
5 & 0.366 & 0.398 & 0.404 & 0.347 & 0.379 & 0.027 & 7.1 \\
6 & 0.481 & 0.535 & 0.485 & 0.407 & 0.477 & 0.053 & 11.1 \\
7 & 0.541 & 0.65 & 0.665 & 0.571 & 0.697 & 0.060 & 9.9 \\
8 & 0.602 & 0.666 & 0.631 & 0.604 & 0.626 & 0.030 & 4.8 \\
9 & 0.761 & 0.847 & 0.869 & 0.732 & 0.802 & 0.066 & 8.2 \\
10 & 0.892 & 0.89 & 0.911 & 0.818 & 0.878 & 0.041 & 4.7 \\
Negative & 0.080 & 0.081 & 0.068 & 0.068 & 0.074 & 0.007 & 9.7 \\
& & & & & Overall mean CV: & 8.1 \\
\hline
\end{tabular}

as a percentage of the maximum absorbance (Kemeny 1991); or in arbitrary units derived from a reference curve (Calamel \& Lambert 1988) such as the equivalent number of bacteria per well or the concentration of bacteria in the bath challenge.

An underlying assumption of a quantitative ELISA is that the results are comparable within and between assays. Therefore, the assay must be well standardized and sample variation must be minimal. In the Flavobacterium branchiophilum ELISA, mean intra-assay and inter-assay variation of approximately 6 to $8 \%$ (coefficient of variation) was achieved under routine assay conditions (Tables $4 \& 5$ ). This low level of variation ensured that estimations of bacterial quantity were comparable among assays.

in the development of only 1 colony from a variable number of cells (Collins \& Lyne 1976). Whatever the explanation we could not correlate the ELISA results to the colony counts on gill tissue from infected fish. Nevertheless, the antigen quantity could be expressed in relative terms such as the ratio of the $O D$ of positive samples to the $O D$ of negative samples (Medina et al. 1992); absolute units of absorbance (Voller et al. 1976);
The use of a quantitative reference curve for estimation of antigen mass also assumes that dilution of a strong positive sample will produce a curve which lies parallel to the reference curve (Kemeny 1991, Hamilton \& Adkinson 1988). This characteristic of the Flavobacterium branchiophilum ELISA was demonstrated with infected gill samples (Fig. 5). If it is necessary to estimate the amount of antigen in a sample
Fig. 5. Flavobacterium branchiophilum. Illustration of parallelism by the dilution of 4 strongly positive gill samples. At the standard gill tissue concentration of $100 \mu \mathrm{g} \mathrm{ml}^{-1}$ the samples produced ELISA absorbances which exceeded the upper limit of the standard curve. Dilution of the samples with coating buffer produced absorbance values parallel to the standard curve. Dilutions are of $100 \mu \mathrm{g} \mathrm{ml}^{-1}$ gill extract

(-) Standard curve: whole-cell $F$ branchiophilum (LAB 4A) (1 to 80000 cells $\mathrm{ml}^{-1}$ ); (+) infected gill samples
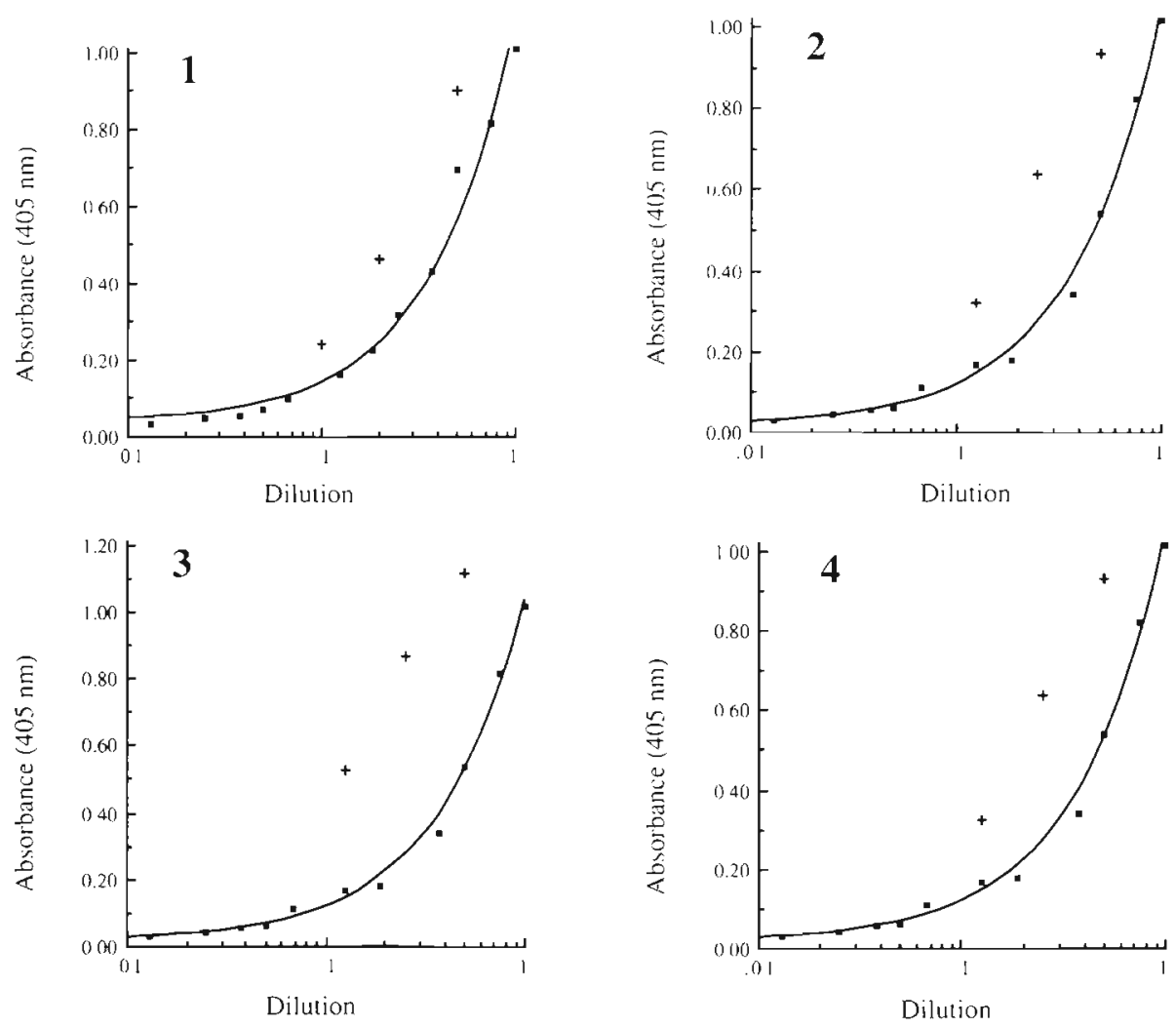
that exceeds the upper limit of the reference curve, the sample is diluted, antigen mass is interpolated from the reference curve, and this is multiplied by the dilution factor to arrive at the final estimate of antigen quantity.

It was difficult to compare the detection threshold of the Flavobacterium branchiophilum ELISA to the detection threshold of bacterial culture, because $F$ branchiophilum recovery was inconsistent. Therefore the limit of detection of the F. branchiophilum ELISA, as compared to bacterial culture, could not be determined. However, the ELISA was strongly positive for all but one of the 28 gill samples which proved to be culture positive (Table 3). Furthermore, many fish exposed to baths of $F$ branchiophilum were culture negative, but positive by the $F$. branchiophilum ELISA (Figs. $3 \& 4$ ). Therefore, it appears that the detection threshold of the ELISA is probably at least as low as that of culture and that the ELISA is considerably more reliable. Should a lower detection threshold be required, purification of the rabbit anti-F branchiophilum serum might prove satisfactory. Purification would allow the biotinylation of the antibody(-bodies), thereby facilitating the development of a sandwich ELISA, which is generally recognized as the most sensitive ELISA technique available (Amadeo et al. 1981, Voller \& Bidwell 1986, Kemeny 1991).

The specificity of the assay was encouraging. There was no cross reaction with 5 other bacteria commonly isolated from the gills, minimal cross reaction with one nonfilamentous Flavobacterium sp. (Table 1) and low background readings for uninfected gill tissue. This degree of specificity is adequate in studies involving the detection of $F$. branchiophilum following experimental exposure of fish to the agent. However, in testing samples collected in the field, the array of potentially cross reacting organisms is far greater. Therefore, further testing against a broader range of common gill bacterial flora would be advisable before using the F. branchiophilum ELISA in field studies.

Although the use of unpurified polyclonal antibodies may result in the detection of a wider range of strains and antigenic variants of Flavobacterium branchiophilum (Xu et al. 1991), it also increases the likelihood of cross reaction with other bacteria. If antigenic specificity proves to be a problem in field work, affinity purification of the antibodies may be required as monoclonal antibodies are not available. In this connection, heat inactivation, absorption with host tissue and partial purification with ammonium sulphate (Harlow \& Lane 1988) produced no improvement in antigenic specificity or the detection threshold (MacPhee unpubl.) Use of antisera raised against specific bacterial cell wall components, such as pili, might also improve the antigenic specificity of this ELISA but this might reduce the sensitivity of the assay as there is considerable antigenic diversity among isolates of $F$. branchiophilum recovered from outbreaks of BGD in Ontario (Ostland et al. 1994). It is also important to recognize that species-specific tissue elements may also interfere with antigen adsorption to the solid phase (Viscidi et al. 1984) and/or cross react with the antibodies in the polyclonal antiserum. Therefore, the use of the assay on a species other than rainbow trout would require optimization of the concentration of gill tissue homogenates for coating the solid phase.

The ELISA to estimate the mass of Flavobacterium branchiophilum antigen on the gill is an important tool for the investigation of the pathogenesis, treatment and prevention of BGD. The F. branchiophilum ELISA offers sensitive, consistent and achievable results, and the testing of large numbers of samples with relative ease. Continuing research facilitated by this assay includes the assessment of the kinetics of bacterial colonization of the gills following exposure to the pathogen, the effect of chloramine- $T$ treatment on colonization; and the effect of feeding on the development of BGD.

Acknowledgements. The Fish Pathology Laboratory receives most of its funding from the Ontario Ministry of Agriculture and Food.

\section{LITERATURE CITED}

Adams A, Thompson K (1990) Development of an enzymelinked immunosorbent assay (ELISA) for the detection of Aeromonas salmonicida in fish tissue. J aquat Anim Health 2:281-288

Amadeo JP, Ford DJ, Makler MT (1981) Properties of enzyme immunoassays. In: Ishikawa $E$, Kawai $T$, Miyai K (eds) Enzyme immunoassay. Igaku-Shoin, Tokyo, p 27-40

Anacker RL, Ordal EJ (1959) Studies on the myxobacterium Chondrococcus columnaris. I. Serological typing. J Bacteriol 78:25-32

Arkoosh MR, Kaattari SL (1990) Quantitation of fish antibody to a specific antigen by an enzyme-linked immunosorbent assay (ELISA). In: Stolen JS, Fletcher TC, Anderson DP, Roberson BS, van Muiswinkel WB (eds) Techniques in fish immunology. SOS Publications, Fair Haven, NJ, p 15-24

Austin B, Bishop I, Gray C, Watt B, Dawes J (1986) Monoclonal antibody-based enzyme-linked immunosorbent assays for the rapid diagnosis of clinical cases of enteric redmouth and furunculosis in fish farms. J Fish Dis 9 $469-474$

Calamel M, Lambert M (1988) E.L.I.S.A. standardized technique. Laboratoire National de Pathologie Petits Ruminants et des Abeilles, Nice

Collins CH, Lyne PM (1976) Microbiological methods, 4th edn. Butterworth, London

Daoust P-Y, Ferguson HW (1983) Gill disease of cultured salmonids in Ontario. Can J comp Med 47:358-362

Dixon PF, Hill BJ (1983) Rapid detection of infectious pancreatıc necrosis virus (IPNV) by the enzyme-linked immunosorbent assay (ELISA). J gen Virol 64:321-330 
Dixon PF, Hill BJ (1984) Rapid detection of fish rhabdoviruses by the enzyme-linked immunosorbent assay (ELISA). Aquaculture 42:1-12

Farkas J (1985) Filamentous Flavobacterium sp. isolated from fish with gill diseases in cold water. Aquaculture 44: $1-10$

Ferguson HW, Ostland VE, Byrne P, Lumsden JS (1991) Experimental production of bacterial gill disease in trout by horizontal transmission and by bath challenge. $J$ aquat Anim Health 3:118-123

Hamilton RG, Adkinson NF (1988) Quantitative aspects of solid phase immunoassays. In: Kemeny DM, Challacombe SJ (eds) ELISA and other solid phase immunoassays: theoretical and practical aspects. John Wiley \& Sons, New York, p 57-84

Harlow E, Lane D (1988) Antibodies: a laboratory manual. Cold Spring Harbor Laboratory, Cold Spring Harbor, NY

Heo G-J, Kasai K, Wakabayashi H (1990) Occurrence of Flavobacterium branchiophilum associated with bacterial gill disease at a trout hatchery. Fish Pathol 25:99-105

Kemeny DM (1991) A practical guide to ELISA. Pergamon Press, Toronto

Kimura N, Wakabayashi H, Kudo S (1978) Studies on bacterial gill disease in salmonids - 1 . Selection of bacterium transmitting gill disease. Fish Pathol 12:233-242

McLaren ML, Lillywhite JE, Andrew CS (1981) Indirect enzyme linked immunosorbent assay (ELISA): practical aspects of standardization and quality control. Med lab Sci 38:245-251

Medina DJ, Chang PW, Bradley TM, Yeh M-T, Sadasiv EC (1992) Diagnosis of infectious hematopoietic necrosis virus in Atlantic salmon Salmo salar by enzyme-linked immunosorbent assay. Dis aquat Org 13:147-150

Mourton C, Bearzotti M, Piechaczyk M, Paolucci F, Pau B, Bastide J-M, de Kinkelin P (1990) Antigen-capture ELISA for viral haemorrhagic septicaemia virus serotype I. J virol Methods 29:325-334

Ostland VE (1989) Bacterial gill disease of salmonids: a description and definition of the disease in Ontario hatcheries. MSc thesis, University of Guelph

Ostland VE, Ferguson HW, Prescott JF, Stevenson RMW, Barker IK (1990) Bacterial gill disease of salmonids; relationship between the severity of gill lesions and bacterial recovery. Dis aquat Org 9:5-14

Ostland VE, Lumsden JS, MacPhee DD, Ferguson HW (1994) Characteristics of Flavobacterium branchiophilum, the cause of salmonid bacterial gill disease in Ontario, Canada. J aquat Anim Health 6:13-26

Pascho RJ, Mulcahy D (1987) Enzyme-linked immunosorbent assay for a soluble antigen of Renibacterium salmoni-

Responsible Subject Editor: T. Evelyn, Nanaimo, B.C., Canada narum, the causative agent of salmonid bacterial kidney disease. Can J Fish Aquat Sci 44:183-191

Romestand B, Dragesco A, Breuil G, Coste F, Bouix G (1993) An ELISA technique for rapid diagnosis of vibriosis in sea bass Dicentrarchus labrax. Dis aquat Org 15:137-143

Sanz F, Coll JM (1992) Detection of haemorrhagic septicemia virus of salmonid fishes by use of an enzyme linked immunosorbent assay containing 2 noncompetitive monoclonal antibodies against early viral nucleoproteins and high sodium chloride concentration. Am $J$ vet Res 53:897-903

Smith PD (1981) Enzyme-linked immunosorbent assay (ELISA) for detection of Aeromonas salmonicida in diseased fish tissue. Develop biol Standard 49:97-100

Speare DJ, Ferguson HW (1989) Clinical and pathological features of common gill diseases of cultured salmonids in Ontario. Can Vet J 30:882-887

Speare DJ, Ferguson HW, Beamish FWM, Yager JA, Yamashiro S (1991a) Pathology of bacterial gill disease: ultrastructure of branchial lesions. J Fish Dis 14:1-20

Speare DJ, Ferguson HW, Beamish FWM, Yager JA, Yamashiro S (1991b) Pathology of bacterial gill disease: sequential development of lesions during natural outbreaks of disease. J Fish Dis 14:21-32

Viscidi R, Laughon BE, Hanavich M, Bartlett JG, Yolken RH (1984) Improved enzyme immunoassays for the detection of antigens in fecal specimens. Investigation and correction of interfering factors. J immunol Methods 67:129-143

Voller A, Bidwell DE, Bartlett A (1976) Enzyme immunoassays in diagnostic medicine. Theory and practice. Bull WHO 53:55-65

Voller A, Bidwell D (1986) Enzyme-linked immunosorbent assay. In: Rose NR, Friedman H, Fahey JL (eds) Manual of clinical immunology, $3 \mathrm{rd}$ edn. American Society for Microbiology, Washington, DC, p 99-109

Wakabayashi H, Egusa S, Fryer JL (1980) Characteristics of filamentous bacteria isolated from gill disease of salmonids. Can J Fish Aquat Sci 37:1499-1504

Wakabayashi H, Huh GJ, Kimura N (1989) Flavobacterium branchiophila sp. nov., a causative agent of bacterial gill disease of freshwater fishes. Int $J$ syst Bacteriol 39: $213-216$

Way K, Dixon PF (1988) Rapid detection of VHS and IHN viruses by the enzyme-linked immunosorbent assay (ELISA). J appl Ichthyol 4:182-189

Xu L, Mourich DV, Engelking HM, Ristow S, Arnzen J, Leong JC (1991) Epitope mapping and characterization of the infectious hematopoietic necrosis virus glycoprotein, using fusion proteins synthesized in Escherichia coli. J Virol 65:1611-1615

Manuscript first received: July 9, 1993

Revised version accepted: August 5, 1994 